\title{
类
}

\section{Die impak van selfmoord op dié wat agterbly}

\author{
G. Breed \& B.J. de Klerk
}

Vakgroep: Praktiese Teologie

Potchefstroomkampus

Noordwes-Universiteit

POTCHEFSTROOM

E-pos: gert@gkrandburg.org.za

kwsbjdk@puk.ac.za

\section{Abstract \\ The impact of suicide on those who are left behind}

In order to offer pastoral guidance to someone who has lost a loved one to suicide, it is essential to be informed on the unparalleled impact that suicide has on those who are left behind. Without this knowledge the pastoral intervention can be rejected or counselling can fail entirely. In this article an attempt is made to firstly discover the nature of suicide and then to establish how many people are touched by suicide. After that the physical and emotional impact on the people who are left behind comes up for discussion. The processing of suicide in relation to its impact as well as its social and spiritual aspects is also investigated. It is important to determine who has been impacted on by the suicide in order to ensure that no one is overlooked during counselling. The trauma has a far-reaching impact on the spiritual lives of those who are left behind and for this reason the spiritual or religious impact of a suicide must be the counsellor's main focus. Although all the other facets should also be thoroughly attended to, true healing cannot take place if an individual's inner struggle and spiritual questions are not addressed.

\section{Opsomming}

Die impak van selfmoord op dié wat agterbly

Ten einde iemand pastoraal te kan begelei na die selfmoord van 'n geliefde, is dit noodsaaklik om kennis te hê van die unieke impak wat selfmoord het op dié wat agterbly. Sonder hierdie kennis kan die pastorale advies verwerp word, of kan berading heeltemal misluk. In hierdie artikel word gepoog om 
eerstens die aard van selfmoord te probeer ontdek en dan na te gaan hoeveel persone deur selfmoord geraak word. Die fisieke en emosionele impak op die persone wat agterbly, kom voorts aan die orde. Ondersoek word ook ingestel na die verwerking van selfmoord as 'n aanduiding van die impak en die sosiale en geestelike aspekte daarvan. Dit is belangrik om seker te maak wie almal deur die selfmoord geraak is, sodat niemand in die berading misgekyk word nie. Hierdie trauma maak 'n ingrypende impak op die geloofslewe van diegene wat agterbly en daarom moet die fokus van die berader op die geestelike of geloofsimpak wees. Alhoewel al die ander fasette noukeurig aangeraak behoort te word, kan daar nie ware genesing plaasvind indien 'n persoon se geloofvrae en -worsteling nie hanteer word nie.

\section{Inleiding}

Die dood van 'n geliefde is op sigself reeds 'n hartverskeurende ervaring. Wanneer 'n geliefde selfmoord pleeg is dit 'n dubbele slag vir die wat agterbly en hulle het geweldig baie om te verwerk (Van der Walt, 1988:4). Daar is gewoonlik twee partye by 'n sterfgeval betrokke: die persoon wat sterf en die wat agterbly. Wat lyding betref, neem die agtergeblewenes die volle impak. Dit is in die besonder waar wanneer iemand selfmoord pleeg (Alexander, 1991: 277). Om hulp te kan verleen aan mense wat deur hierdie pyn gaan, moet daar begrip wees vir wat selfmoord is en watter impak dit het op dié wat agterbly. Mense met vooroordele oor die een wat selfmoord gepleeg het en hulle naasbestaandes, kan moeilik dié wat agterbly, help (Wertheimer, 1991:11)

Die vraag wat in hierdie artikel ondersoek word, is: Wat is die impak van selfmoord op die naasbestaandes wat agterbly en watter implikasie het dit vir die pastoraat? Die metode wat in hierdie ondersoek gevolg word, is 'n literatuurstudie uit die tersaaklike bronne, waarna telkens afleidings vir die pastoraat gemaak sal word. Die werksplan is om eerstens die aard van selfmoord te probeer ontdek en dan na te gaan hoeveel persone deur selfmoord geraak word. Die fisieke en emosionele impak op die persone wat agterbly kom daarna aan die orde. Daar word ook ondersoek ingestel na die verwerking van selfmoord as ' $n$ aanduiding van die impak en die sosiale en geestelike aspekte daarvan. Ten slotte sal gepoog word om samevattings met die oog op die pastoraat te formuleer. 


\section{Die aard van selfmoord}

Selfmoord is die doelbewuste beëindiging van jou eie lewe. Alexander (1991:277) sê van selfmoord:

A chosen death, carried out alone and often secretly, suicide is perhaps the most profound act of disconnection from one's own self and life, from others who have been part of one's life, and from human community. The secrecy, isolation, and disconnection that frame the act of suicide become the survivor's legacy, making grief especially difficult and complex.

Met survivor bedoel sy die mense wat na 'n voltooide selfmoord agterbly.

By hierdie definisie kan die doel van selfmoord gevoeg word. Selfmoord is dikwels daarop gerig om te ontsnap aan 'n skynbaar ondraaglike situasie, of dit kan 'n daad van wraak wees wat bedoel is om dié wat agterbly seer te maak (Seeber, 2002:31). Douglas (1967:322), steeds 'n gesaghebbende bron oor selfmoord, sê dat dit altyd ook 'n kommunikasiemetode is waardeur die een wat selfmoord pleeg invloed uitoefen op die wat agterbly.

Vanaf die vroegste tye het skrywers reeds die impak van selfmoord beskryf. Aristoteles (soos aangehaal deur Battin, 1982:77) beskou selfmoord as 'n oortreding teen die staat. Selfmoord doen volgens hom die gemeenskap skade aan en is daarom verkeerd.

Wertheimer (1991:19-24) identifiseer die volgende faktore wat die impak van selfmoord anders maak as die impak van ander verliese en dus die verwerkingsproses kompliseer:

- Die wyse waarop die persoon sterf: dikwels geheimsinnig, en gewoonlik gewelddadig.

- Gebeure wat in die aanloop tot die selfmoord plaasgevind het, kan skuldgevoelens, selfverwyt en selfs vrees by die agtergeblewenes aanwakker.

- Die onbeantwoorde vrae wat deur die selfmoord gewek word by die wat agterbly.

- Die betrokkenheid by en ondersoek van die polisie wat die gevoel skep dat daar 'n kriminele oortreding was.

- Die feit dat daar aanvanklik geen privaatheid is nie, want ondersoekbeamptes, fotograwe, mediese personeel en vreemdelinge, neem jou huis oor wanneer die selfmoord daar plaasgevind het. 
- Die verwerking van geloofsvrae oor die eindbestemming van die een wat selfmoord gepleeg het, eie skuld en vergifnis.

- Die verwerking van die selfmoord as 'n familie. Elkeen se eie rouproses en die verskille tussen lede van die gesin, kan onderlinge verhoudings versuur.

- Om ander mense in die oë te kyk na die selfmoord.

- Die vrees vir veroordeling of minagting.

Vanuit die voorgaande kan gekonkludeer word dat daar tydens pastorale begeleiding vasgestel sal moet word:

- watter skokreaksie daar is vanweë 'n geweldadige selfmoord;

- watter impak daar gemaak is op dié wat agterbly deur hierdie daad van permanente onttrekking (diskoneksie);

- watter boodskap(pe) hierdie skokkende daad aan elke individu wat agterbly, oorgedra het;

- watter vrae hierdie gebeurtenis gewek het by dié wat agterbly;

- watter gevoelens ander mense se optrede by die persoon gewek het;

- watter verskille daar by gesinslede in die rouproses is.

\section{Die aantal persone geraak deur 'n selfmoord}

Barlow en Morrison (2002:29) haal die American Academy of Suicidology (1997) aan wat beweer dat minstens ses mense deur een selfmoord geraak word. Die getal persone wat direk en intens geraak word, kan egter so hoog wees as twintig (Gifford \& StuartSmith, 1993:34). Mense wat geraak word, maar aan wie nie altyd gedink word nie, is byvoorbeeld die persoon se dokter of psigiater, persone wat die lyk gevind het, die polisie wat die saak ondersoek, die patoloog wat die na-doodse ondersoek doen, mense met wie hy/sy in belangrike saketransaksies betrokke was en selfs iemand met wie die persoon 'n buite-egtelike of geheime verhouding gehad het (Wertheimer, 1991:15). Mauk en Gibson (1994:469, 472) toon aan dat die selfmoord van 'n leerling 'n impak maak op die hele skool se leerlinge en leerkragte en deur hulle, ook op hulle gesinne. So kan 'n hele gemeenskap die trauma van 'n selfmoord in 'n mindere of meerdere mate voel. Hulle toon ook aan (Mauk \& Gibson, 1994:469) dat verskeie skrywers die gevaar uitwys dat kinders in ' $n$ bepaalde skool of omgewing die voorbeeld van self- 
moord kan navolg en dat verskeie selfmoorde in een skool of omgewing kan plaasvind. Hierdie tendens is in Suid-Afrika bevestig deur die selfmoord van drie kinders kort na mekaar in die PretoriaCenturion omgewing (Du Toit, 2004:6). Dit word bevestig deur Barlow en Coleman (2003:69): "Indeed, children with one or more family member who has commited suicide have a greater risk of attempting suicide compared to other children with no suicide in the family."

Rassool (2002) sê dat die Wêreld Gesondheidsorganisasie se statistiek aantoon dat Suid-Afrika se selfmoordsyfer onder tieners die hoogste ter wêreld is en dat ses uit elke honderdduisend tieners hier selfmoord pleeg. Wanneer ' $n$ kind byvoorbeeld selfmoord pleeg moet nie net sy broers, susters en ouers berading ontvang nie, maar ook grootouers en ander familielede wat naby aan hierdie kind was (Strength, 1999:346).

Hieruit blyk dat dit belangrik sou wees om seker te maak op wie almal die selfmoord ' $n$ impak gemaak het, sodat niemand in die berading misgekyk word nie.

\section{Fisieke impak van selfmoord op die mense wat agterbly}

Barlow en Morrison (2002:37) wys daarop dat die skok en stres wat selfmoord ontketen by dié wat agterbly ook fisieke reaksies in 'n mens se liggaam te weeg bring (vgl. ook Kalischuk \& Hays, 2004: 55). Thompson (1993:18) wys op die volgende veranderinge in die liggaam: verhoogde bloeddruk, respirasie en spieraktiwiteit. Indien dit nie behandel word nie, kan hart-, asemhalings- en spysverteringsprobleme ontstaan. Hiermee saam kan iemand 'n intense moegheid, angstigheid en gebrek aan eetlus beleef. Alhoewel dit nie wenslik is om iemand deur medikasie te beroof van die aanvanklike verwerkingsproses nie, kan dit tog nodig wees om mediese hulp in te roep, asook om ontspanningsoefeninge voor te skryf.

Onderdrukking of ontkenning van die gebeure en die emosies wat daarmee saamgaan, kan lei tot fisieke ongesteldhede en dit vergroot die impak toenemend (Linn-Gust, 2006:3).

Uit voorafgaande is die volgende duidelik:

- Die pastorale berader moet nóú saamwerk met ander professionele persone wat hy vertrou en wat die mediese aspekte van trauma kan hanteer. 
- Die fisieke impak wat die traumatiese ervaring op hulle kan hê moet aan dié wat na selfmoord agterbly verduidelik word - veral aan kinders.

\section{Emosionele impak}

Daar is soveel faktore wat die emosionele impak van selfmoord op die wat agterbly beïnvloed dat dit onmoontlik sal wees om ' $n$ eenvormige beskrywing te gee van die emosies wat so 'n persoon kan ervaar (Gifford \& Stuart-Smith, 1993:34; Seeber, 2002:29). Elke persoon is uniek ten opsigte van die emosies wat hy/sy beleef. Elkeen wat hierby betrokke is, gaan egter emosies beleef en daar bestaan 'n groot ooreenkoms in die emosies wat mense in sulke situasies beleef (Wertheimer, 1991:17, 18). Indien hierdie emosies nie reg verwerk word nie, kan dit aanleiding gee tot nog meer en ingewikkelder emosies. Selfs wanneer die trauma ten beste verwerk word, sal dié wat agterbly na die selfmoord van 'n geliefde vir die res van hulle lewe moet saamleef met die verlies. Hulle sal herhaaldelik, op verskeie wyses aan die selfmoord herinner word en dit telkens dalk weer moet verwerk (Christian, 1997:87).

Weens die beperkte omvang van hierdie artikel word hier slegs kortliks stilgestaan by emosies wat ouers wat 'n kind verloor het, kan ervaar en daarna by dié van 'n kind wat 'n ouer, broer, suster of ander familielid ná aan hom verloor het. 1

\subsection{Emosionele impak op ouers}

Christian (1997:86) beskryf die emosionele impak van 'n kind se selfmoord op 'n ouer soos volg:

During the sleepless night that follows, your sense of rejection sours into bitterness. How could he have done this to me? Your grief turns to shame as you think of explaining this to relatives, friends, the congregation. As this shame takes hold, you begin to feel a loneliness so intense you doubt anyone could penetrate it.

Oliver (1999:198) identifiseer die volgende waarskynlike emosies by 'n ouer wat agterbly na 'n voltooide selfmoord: hartseer, wanhoop, hulpeloosheid, eensaamheid, verlatenheid en 'n begeerte om te sterf. Ouers wat 'n kind deur selfmoord verloor, verloor ook 'n klomp

$1 \quad$ Vir ' $n$ volledige bespreking van die uitwerking en verwerking van selfmoord deur 'n familie as 'n eenheid, vergelyk Wertheimer (1991:106-115). 
drome, verwagtings en hoop vir die toekoms, asook gevoelens van leegheid en nutteloosheid - 'n diepe teleurstelling in die lewe wat voorlê ( Wertheimer, 1991:117; Kalischuk \& Hays, 2004: 46). Hopmeyer (1994:245) sê dat hierdie emosies voortvloei uit 'n verlies aan simboliek wat deur die kind verteenwoordig was. Hierby kom ook skuldgevoelens, selfverwyt en negatiewe of verwytende reaksies van ander mense wat gevoelens van verwerping en minderwaardigheid kan laat ontwikkel.

Ouers se selfbeeld in verhouding met hulle kind kan ook aan skerwe geruk word. Hulle het hulself nog altyd gesien as die beskermers van hulle kind. Nou staan hulle so totaal magteloos. Hulle kon hulle kind nie beskerm teen hierdie onheil nie, en sal dit ook nooit weer kan doen nie. Die finaliteit van die daad laat hulle nie net twyfel oor hulle vermoë om vir hulle kind te sorg nie, maar of hulle op enige vlak van hulle lewe, wanneer dit regtig saak maak, in staat gaan wees om te doen wat hulle moet doen. Ouers kan dus 'n totale vertwyfeling in hulle eie vermoëns ervaar (Murphy, 1996:445). Hierdie gevoelens lei maklik tot intense woede wat gerig kan wees teen God, ander mense, die kerk of hulleself. Hieruit kan weer haat, selfveragting en bitterheid groei. Dit kan egter ook lei tot depressie, onttrekking en apatie (Oliver, 1999:198; Brent et al., 1996:253; Wertheimer, 1991:118, 119).

Die emosionele worstelinge van die bedroefde ouers kan daartoe aanleiding gee dat hulle ' $n$ weerstand of onvermoë teenoor ander emosionele kontak opbou. Vir sommige vroue is seksuele kontak met haar man na die dood van 'n kind dikwels so 'n sterk herinnering aan die verwekking van die kind, dat sy glad nie daarin belangstel nie. Die man, aan die ander kant, kan tydens die rouproses 'n verhoogde behoefte aan seksuele kontak beleef (Oliver, 1999: 209). Dit kan tot huwelikskonflik lei wat die gevoel van eensaamheid en verwerping kan versterk. Golden (2005:1) verwys na navorsing wat toon dat hormone en die verskil in die uitwerking daarvan op mans en vroue, ook ' $n$ belangrike rol speel in die reaksie op trauma en die gevolglike verwerking daarvan.

Wanneer ouers emosionele kontak met oorblywende kinders maak, word die verlies van die ander kind geaksentueer. Dit kan daartoe lei dat ouers bewustelik of onbewustelik kontak met hulle kinders vermy. Hierdie optrede kan weer tot nuwe emosionele spanning lei wanneer die man, vrou of kinders negatief op hierdie afsydigheid reageer (Strength, 1999:345). Die worsteling met onbeantwoorde vrae en met emosies en die gevolge van emosionele optrede kan so alles-oorheersend raak dat daar geen belangstelling na buite meer 
is nie en dat die sin van die lewe vir hierdie persoon verlore gaan (Wertheimer, 1991:68).

Met die oog op die pastoraat kan die volgende afgelei word:

- Die besondere impak wat die selfmoord van 'n kind op ouers het, moet versigtig vasgestel word, veral die invloed wat dit op die selfbeeld van die ouer het.

- Die gevolge wat die emosionle impak op die huweliksverhouding het, moet bespreek en die nodige begeleiding gedoen word.

- Alle aspekte van die huweliksverhouding wat deur die trauma beïnvloed is, sal gaandeweg gehanteer moet word.

- Begeleiding om weer na buite te kan leef, sal 'n belangrike deel van die berading uitmaak.

\subsection{Emosionele impak op kinders}

Wanneer 'n ouer selfmoord pleeg, veral 'n ouer met wie die kind noue bande gehad het, word 'n groot deel van 'n kind se sekuriteit op 'n skokkende wyse uit sy lewe weggeruk. Vrae en vrese wat hy/sy nie eers kan verwoord nie, woed in sy/haar gemoed. Die kind se vertroue in volwassenes en daarmee saam alle mense om voorspelbaar en selfbeheersd op te tree, word vernietig. Wanneer die trauma nie reg verwerk word nie, word dit telkens herbeleef wanneer daar weer 'n verlies in die kind se lewe voorkom: "subsequent losses or life events reactivate the unresolved original loss" (Heikes, 1997:359).

Indien die kind nog altyd by sy ouer aanvaarding en liefde ervaar het, kan hierdie daad ' $n$ geweldige verwarring in die gemoed van die kind skep. Die kind wat agterbly beleef die selfmoord ook as die uiterste daad van verwerping - die één mens by wie hy/sy aanvaarding gevind het, het hom/haar nou so radikaal en onherroeplik verwerp.

By kinders wat een ouer deur selfmoord verloor, is die vrees vir die verlies van die ander ouer op dieselfde wyse, gewoonlik 'n werklikheid. Hulle kan ook intense bekommernis ervaar oor die moontlike genetiese oorsprong en daarmee oorerflikheid van die neiging tot selfmoord, asook skaamte daaroor dat dit in hulle familie voorkom (Barlow \& Coleman, 2003:69). Wanneer die oorblywende ouer of ouers, in die geval van die selfmoord van 'n boetie of sussie, self emosioneel deur die gebeurtenis ontwrig is, kan die oorblywende 
kinders verwerping en verwardheid beleef, aangesien die ouer moontlik nie meer so by die kinders betrokke sal wees soos hulle gewoond was nie (Leuvennik, 2002:159). Kinders voel hulself dikwels verantwoordelik om hulle ouers te troos oor die dood van 'n broer, suster of huweliksmaat, maar aan die ander kant wil die kind graag aangaan met sy/haar eie lewe. Indien die ouers nie die selfmoord kan verwerk nie en langdurig treur, kan die kind tussen hierdie twee lojaliteite in twee geskeur word (Wertheimer, 1991: 122).

Kinders worstel ook dikwels met intense skuldgevoelens oor hulle optrede teenoor die oorledene voor die selfmoord en hoe dit bygedra het tot die selfmoord (Linn-Gust, 2006:3). Indien ouers die kind wat selfmoord gepleeg het, idealiseer ten koste van die kinders wat nog lewe, kan die oorblywende kinders gevoelens van haat en bitterheid teenoor die afgestorwene en hulle ouers ervaar. Dit kan weer lei tot skuldgevoelens, selfveragting, hopeloosheid en rebelsheid (Strenght, 1999:346). Al hierdie emosies wek dikwels by hierdie kinders gedagtes om ook selfmoord te pleeg om daardeur die situasie te ontkom of om ouers van wie hulle verwerping ervaar, seer te maak (vgl. Wertheimer, 1991:xvii).

Wanneer kinders na die selfmoord van 'n geliefde of kennis pastoraal bedien word, is die volgende daarom belangrik:

- Die unieke vrae en emosies waarmee elke kind worstel moet vasgestel en hanteer word.

- Daar mag nie van die veronderstelling uitgegaan word dat 'n kind wat by is by die berading aan sy ouers, voldoende hulp ontvang het nie.

- Kleiner kinders moet deur verskillende beradingsmetodes (soos spelterapie) gehelp word om hulle vrae en emosies te verwoord (vgl. Heikes, 1997).

\subsection{Verwerking van selfmoord as 'n aanduiding van die impak}

Die impak wat selfmoord op die agtergeblewenes het, word ook duidelik wanneer die pad na herstel of na 'n gekompliseerde reaksie, bestudeer word. Verskeie skrywers identifiseer fases waarin die verwerkingsproses kan plaasvind (Thompson 1993:18; Wertheimer, 1991:44-46; Seeber, 2002:33-37; Pietilä, 2002:402-403; Van der Walt ,1988:28-39). 
- Die krisis of hulpkreetfase (emergency or outcry phase) is 'n verhoogde "veg of vlug"-reaksie op die lewensbedreigende situasie. Hierdie fase duur so lank as wat die oorlewende glo dit moet duur en dit gaan gepaard met verhoogde polslag, bloeddruk, respirasie en spieraktiwiteite. Hiermee saam word gewoonlik gevoelens van vrees en magteloosheid ervaar. Wanneer daar begrip kom dat die gebeurtenis verby is, tree daar gevoelens van verligting en/of verwarring in. Die eerste vrae wat opkom is "waarom?" en "wat nou?" (vgl. ook Wertheimer, 1991:44-46). Hierdie fase kan na selfmoord besonder intens wees, aangesien daar soms geen antwoorde op al die baie vrae bestaan nie. Die agtergeblewenes voel dikwels geïsoleerd van ander mense. Hulp wat aangebied word, word dan met agterdog bejeën, omdat hulle voel dat ander nie kan begryp wat hulle ervaar nie.

- Die fase van emosionele doodsheid, ontkenning en of ontvlugting (the emotional numbing and denial phase) volg nou. 'n Selfbeskermingsdrang laat die oorlewende die volle impak van die gebeurtenis in sy onderbewussyn onderdruk. Hierdie vermydingstegniek verminder spanning- en angssimptome tydelik. Dit is belangrik dat persone, indien hulle dit verlang, in hierdie fase toegelaat word om die liggaam van die oorledene te sien en selfs vas te hou (Wertheimer, 1991:44-46,184-185). Sonder professionele hulp, kan iemand maklik in hierdie fase stagneer. $\mathrm{Na}$ selfmoord is die versoeking altyd daar dat die wat agterbly dit nie bekend maak dat dit selfmoord was nie, omdat selfmoord so gestigmatiseerd is. Soms kan hierdie geheimhouding selfs in samewerking met die polisie en ander hulpdienste plaasvind. Dit veroorsaak dat die treurendes nooit openlik kan praat oor die besondere vrae en pyn wat hulle beleef en wat uniek is na die selfmoord van 'n geliefde nie. Daar bestaan 'n wesenlike gevaar dat persone dan in ontkenning kan voortleef en dit het ' $n$ gekompliseerde verwerkingsproses tot gevolg.

- In die fase van herhaalde onwillekeurige denke (the intrusivetransition phase) dring beelde, nagmerries en skokgolwe die denke van die oorlewende binne, buite sy eie beheer (Wertheimer, 1991:185). Die oorlewende kan herhalende nagmerries kry, gemoedskommelinge ervaar, skrikwekkende beelde "sien" en skokreaksies toon. Ander afbrekende optrede soos woedebuie kan ook voorkom as deel van die persoon se verdedigingsmeganisme teen die pyn, vernedering en onsekerheid wat die trauma te weeg gebring het. Die geweldadige en skokkende aard van selfmoord kan hierdie fase besonder intens maak. 
- Gedurende die nadenke en oorgangsfase (reflective-transition phase) word die gebeure beoordeel. Die getraumatiseerde stel vir hom-/haarself vas watter betekenis dít wat gebeur het vir die lewe en die sin van die lewe het. Die oorlewende begin die traumatiese gebeure óf in die regte perspektief, óf in 'n verwronge perspektief sien. Hy/sy begin óf positief dink aan die toekoms en kan die trauma algaande agter hom/haar plaas, óf die trauma oorheers sy/haar lewe negatief op 'n minder of meer ingrypende wyse. Probleme word óf in die oë gekyk en na oplossings gesoek (Wertheimer, 1991:185-186), óf as só onoorkomelik beskou dat die getraumatiseerde oortuig raak dat hy/sy 'n slagoffer is. Wanneer daar tot laasgenoemde negatiewe oortuigings gekom word, voel die slagoffer uitgelewer. Die vastighede is weggeruk uit sy/haar lewe en hy/sy leef in die vrees vir die volgende ramp wat hom/haar enige oomblik kan tref.

- In die integrasiefase (integration phase) integreer die oorlewende die trauma met al sy/haar vorige ervarings en kan dan met sy/haar lewe voortgaan. Die trauma word ten volle agter hom/ haar geplaas (Wertheimer, 1991:194, 195). Die lewe kan egter ook onder die wolk van negatiewe vrese geleef word sodat die trauma 'n permanente deel van sy/haar lewe word.

Van der Walt (1988:28-39) identifiseer drie fases in die rouproses naamlik: skok, soeke (vgl. fase 1 en 2 hierbo); verlange en protes (vgl. fase 3 hierbo); en heraanpassing (vgl. fase 4 en 5 hierbo). Indien die trauma reg verwerk word, volg hierdie fases mekaar in ' $n$ vaste patroon op, maar die tyd wat 'n individu in 'n bepaalde fase bly, mag verskil. Die getraumatiseerde mag in enige van hierdie fases vasval.

Onlangs is die patroonmatige verloop van die verwerking van trauma egter bevraagteken (Kalischuk \& Hays, 2004:46; Neimeyer et al., 2006:27, 28). Die verwerking van trauma word eerder gesien as 'n dinamiese proses wat deur verskeie persoonlike veranderlikes beïnvloed word. Verwerking van trauma is daarom onlosmaaklik deel van 'n proses waarin die getraumatiseerde moet uitmaak wie hy/sy werklik is (Kalischuk \& Hays, 2004:46). Selfmoordtrauma het dus nie net 'n impak op die mens se emosies nie, maar op die wyse waarop hy-/sy hom-/haarself, sy/haar lewe en die werklikheid rondom hom-/haarself sien.

Neimeyer et al. (2006: 27, 28) sê dat navorsing aangetoon het dat een van die belangrikste faktore wat die verwerkingsproses beïnvloed, die vind van die sin van die verlies is. Aangesien die persoon 
wat agterbly dikwels moet worstel om die doel van die selfmoord te bepaal, kan die verwerkingsproses hierdeur ernstig beïnvloed word.

Die betekenis van die voorafgaande vir die pastoraat kan soos volg saamgevat word:

- Die berader moet noukeurig vasstel watter emosies die persoon wat hy/sy bystaan, ervaar.

- Die berader moet begrip hê vir die uniekheid van elke persoon se verwerkingsproses soos dit voortvloei uit sy/haar besondere verhouding met die een wat selfmoord gepleeg het.

- Die berader moet weet deur watter fases die agtergeblewenes kan gaan en voortdurend evalueer of daar vordering in die verwerkingsproses is.

- Die berader moet begrip hê dat selfmoord 'n groot potensiaal by die agtergeblewenes skep om in die verwerkingsproses vas te val.

\section{Sosiale impak}

Die selfmoord van iemand wat 'n groot rol in 'n persoon se lewe gespeel het, beïnvloed so 'n persoon se verhouding met ander mense intens. Hierdie uitwerking kan ten beste verwoord word met die vrae wat so persoon vir hom-/haarself moet beantwoord.

\subsection{Is ek in staat tot sinvolle verhoudings met ander mense?}

Hierdie vraag kom by dié wat agterbly met groot intensiteit op vanuit die belewing van die verwerping deur die een wat selfmoord gepleeg het. Deur die selfmoord het die oorledene gesê dat 'n lewe saam met die een wat agterbly so min aanvaarbaar is, dat hy/sy liewer sal selfmoord pleeg om daaraan te ontkom. Of die een wat selfmoord gepleeg het dit inderdaad as ' $n$ daad van verwerping bedoel het, is nie ter sake nie; die een wat agterbly ervaar dit dikwels so. Hieruit word die vraag gebore of die een wat agterbly in ander verhoudings sal kan slaag as dit nie in hierdie belangrike verhouding die geval was nie. Dit kan veroorsaak dat so 'n persoon as gevolg van 'n lae selfbeeld onttrek van ander verhoudings of onseker raak in die omgang met ander mense (Barlow, 2003:4).

\subsection{Wat dink ander mense van my?}

Vroeër was daar strafmaatreëls geneem teen die agtergeblewenes van ' $n$ selfmoordenaar. Dit het onder andere ingehou dat in som- 
mige gevalle beperkings op 'n normale begrafnis ingestel is, agtergeblewenes hulle eiendom ontneem is, en weduwees gedwing is om ook selfmoord te pleeg (Van der Walt, 1988:5; Balch, 1964:26). Alhoewel hierdie strawwe buite verhouding ernstig klink, het die samelewing vandag nog sy eie stel optredes wat as strafmaatreëls ervaar kan word deur die wat na selfmoord agterbly. Dit trek saam in die eenvoudige, maar kritiese vraag: Wat dink ander mense van my? Vrees en onsekerheid by familie en vriende van die wat agtergebly het, kan vermyding tot gevolg hê, omdat hulle nie weet hoe om teenoor agtergeblewenes op te tree of hulle in hulle smart te troos nie (Knieper, 1999:357). By die broers en susters, ouers of vriende van die een wat selfmoord gepleeg het, kan daar inderdaad die vraag wees of die eggenoot of kinders nie die selfmoord kon gekeer het nie. Die oortuiging kan selfs posvat dat die selfmoordenaar "daartoe gedryf" is. Dit kan veroorsaak dat die hulp en bystand wat familie en vriende normaalweg gee, afwesig is. Selfs wanneer hierdie vrae nie by ander leef nie, kan die naasbestaandes van die een wat selfmoord gepleeg het, by hulself wonder of oortuig raak dat ander wel dink dat hulle skuld het aan die selfmoord. Strength (1999:342) sê dat skuldgevoelens dikwels 'n oorheersende rol in die wat na selfmoord agterbly se verhouding met ander mense speel. Hierdie skuldgevoelens kan weer daartoe aanleiding gee dat hulle heeltyd op die verdediging is en op hierdie wyse mense van hulle wegdryf (Gifford \& Stuart-Smith, 1993:35).

Knieper (1999:356) toon aan dat mense wat na selfmoord agterbly soms selfs die bystand wat hulle wel ontvang, nie as werklike bystand ervaar nie. 'n Groot deel van die stigma wat die wat agterbly ervaar, kan dalk in hulle eie vrees vir verwerping lê, en dit kan hulle blind maak vir die omgee wat hulle wel ontvang. Knieper (1999:357) haal Kathy Jones aan wat sê dat tydens haar moeder, wat selfmoord gepleeg het, se begrafnis, het die enigste werklike troos gekom van iemand wat ook 'n geliefde deur selfmoord verloor het. Dit mag wees dat die vooroordeel wat veroorsaak het dat sy ander se troos geblokkeer het, weggeval het by hierdie persoon wat deur dieselfde trauma as sy is (vgl. ook Wertheimer, 1991:134-147).

\subsection{Is dit die moeite werd om in 'n noue verhouding betrokke te raak?}

Die vertrouenskok wat iemand ervaar as gevolg van die selfmoord het ook 'n invloed op sy/haar siening van nabyverhoudings. Oliver (1999:221) stel die onverwagse dood van 'n geliefde "can therefore severely impair the individual's sense of safety, security and trust in 
relationships with others". Daar bestaan 'n huiwering by die wat na 'n selfmoord agterbly om weer in 'n noue verhouding betrokke te raak uit vrees vir die seerkry wat dit kan meebring. Hulle weeg die vreugde van 'n verhouding met 'n naby vriend of familielid op teen die seerkry wat daardeur in hulle lewe gekom het. Baie besluit om hulleself die swaarkry te spaar, al moet hulle alle ware vriendskap ontbeer.

\subsection{Kan enigiemand anders sinvol praat oor dit wat ek/ons ervaar?}

Pietilä (2002:406) dui vanuit verskeie onderhoude aan dat persone wat die selfmoord van 'n geliefde ervaar het, dikwels oortuig is dat net hulle sinvol kan dink en praat oor die gebeurtenis. In hulle gemoed "besit" hulle hierdie gebeurtenis en daarom het hulle ook die reg om te bepaal wie toegang daartoe mag hê. Mense wat nie deur 'n soortgelyke gebeurtenis gegaan het nie se gepoogde hulp word maklik beskou as indringing in iets wat hulle nooit sal kan begryp nie (Linn-Gust, 2006:1). Tog is daar die behoefte dat ander mense betrokke moet wees en met die bedroefde moet gesels: "The interviewees' accounts, therefore, involved a contradiction in describing both wanting others to help them and disqualifying them from helping." (Pietilä, 2002:406.) Dikwels voel die bedroefde dat hy/sy die reg aan ander moet toeken om oor hierdie gebeure te mag praat. Verskillende mense word dan tot op verskillende vlakke toegelaat. Mense wat deur soortgelyke traumatiese gebeure gegaan het, word dikwels beskou as "kenners" wat die reg het en bevoeg is om relevante raad te gee (Pietilä, 2002:404).

Uit die voorafgaande is die volgende duidelik:

- Die berader moet vasstel met watter vrae die agtergeblewene worstel ten opsigte van sy sosiale verhoudings.

- Die wanopvattings wat daar mag wees moet geïdentifiseer en saam deurgewerk word.

- Die berader kan dit nie as vanselfsprekend aanvaar dat hy/sy sondermeer toegang gegun sal word tot die ervaringswêreld van die bedroefdes nie. Hy/sy sal met groot sensiwiteit moet werk sodat hierdie toegang aan hom/haar toegeken kan word.

\section{Geestelike impak}

Trauma ruk die mens tot stilstand. Dit is soos 'n inbreker wat met geweld toegang tot iemand se privaatheid gekry het en met 'n ruwe 
en ongeërgde hand al die kosbaarhede in die persoon se lewe uitgooi, gebruik, breek en met minagting behandel. Na die trauma staan die mens verslae midde-in die chaos en kyk met nuwe oë na dinge wat eens so vanselfsprekend kosbaar was, so maklik sin gemaak het. Daar kom 'n herevaluering daarvan. Die fisieke en emosionele trauma sypel deur na die mens se oortuigings, ruk dit ook om en bevraagteken elkeen daarvan. Oliver (1999:199) sê die dood van 'n kind "violates basic expectations or beliefs about order and justice in the universe". Ouers wat die sin van hulle lewe grootliks in hulle kind gevind het, staan voor die keuse: "either bringing into question their core beliefs about the universe, or having to deny the painful reality of death". Die selfmoord van 'n geliefde bring die mens in 'n bestaanskrisis waar die heel basiese sekuriteit en betekenis van die lewe en interpersoonlike verhoudings brutaal bevraagteken word.

Wanneer iemand wat jy vertrou het, jou deur sy selfmoord verwerp, word jou beeld van wie jy is en wat jy kan glo, aan skerwe geslaan. "Binne jou word die diepe teleurstelling in liefde en vertroue 'n kanker wat alle geloof in ander mense en in God wil wegvreet." Die trauma beroof jou van die sekerheid van jou oortuigings, jy staan daar leeg van vastighede. Dit is asof jy opnuut elke oortuiging oor God, die werklikheid, veiligheid en verhoudings, jou eie moet maak - of verwerp. Jy vra oor elke oortuiging: "kan ek dit nog glo?" Jy weet nie. En jy voel skuldig omdat jy twyfel. Jy voel beroof, ingedoen en bedrieg. Dit alles plaas jou onder geweldige stres.

Vir die pastoraat hou dit die volgende in:

- Die geestelike of geloofsimpak van 'n selfmoord is die kern waarop die berader moet fokus.

- Alhoewel aan al die ander fasette noukeurig aandag gegee moet word, kan daar nie ware genesing plaasvind alvorens ' $n$ persoon se geloofsvrae en -worsteling nie hanteer word nie.

\section{Samevatting met die oog op die pastoraat}

Tydens pastorale begeleiding moet die volgende vasgestel word:

- Watter skokreaksie is daar vanweë 'n geweldadige selfmoord?

- Watter impak is gemaak op dié wat agterbly deur hierdie daad van permanente onttrekking (diskoneksie)? 
- Watter boodskap(pe) het hierdie skokkende daad aan elke individu wat agterbly, oorgedra?

- Watter vrae het hierdie gebeurtenis by die wat agterbly gewek?

- Watter gevoelens het ander mense se optrede by die persoon gewek?

- Watter verskille is daar by gesinslede in die rouproses?

* Dit is belangrik om seker te maak op wie almal die selfmoord 'n impak gemaak het, sodat niemand in die berading misgekyk word nie.

Die impak van selfmoord op die wat agterbly is ook fisiek en daarom moet op die volgende gelet word:

- Die pastorale berader moet nóú saamwerk met ander professionele persone wat hy/sy vertrou en wat die mediese aspekte van trauma kan hanteer.

- Die fisieke impak wat die traumatiese ervaring op hulle kan hê, moet aan dié wat na selfmoord agterbly, verduidelik word - veral aan kinders.

Die emosionele impak van 'n kind se selfmoord op die ouers noodsaak die volgende:

- Die unieke impak wat die selfmoord op die individuele ouer het, moet versigtig vasgestel word - veral die invloed wat dit op die selfbeeld van die ouer het.

- Die gevolge wat die emosionele impak op die huweliksverhouding het, moet bespreek word en die nodige begeleiding moet gedoen word.

- Alle aspekte van die huweliksverhouding wat deur die trauma beïnvloed is, behoort gaandeweg hanteer te word.

- Begeleiding om weer na buite te kan leef, moet 'n belangrike deel van die berading uitmaak.

Wanneer kinders na die selfmoord van 'n geliefde of kennis pastoraal bedien word, is hulle behoeftes uniek:

- Die unieke vrae en emosies waarmee elke kind worstel moet vasgestel en hanteer word. 
- Daar mag nie van die veronderstelling uitgegaan word dat 'n kind wat slegs by is by die berading aan sy ouers, voldoende hulp ontvang het nie.

- Kleiner kinders moet deur verskillende beradingsmetodes (soos spelterapie) gehelp word om hulle vrae en emosies te verwoord (vgl. Heikes, 1997).

Die emosionele impak wat selfmoord het op die wat agterbly, is verreikend:

- Die berader moet noukeurig vasstel watter emosies die persoon wat hy/sy bystaan, ervaar.

- Die berader moet begrip hê vir die uniekheid van elke persoon se verwerkingsproses soos dit voortvloei uit sy besondere verhouding met die een wat selfmoord gepleeg het.

- Die berader moet weet deur watter fases die agtergeblewenes kan gaan en moet voortdurend evalueer of daar vordering in die verwerkingsproses is.

- Die berader moet begrip hê dat selfmoord 'n groot potensiaal skep by die agtergeblewenes om in die verwerkingsproses vas te val.

Die sosiale impak van selfmoord op die wat agterbly, is beduidend:

- Die berader moet vasstel met watter vrae die agtergeblewene worstel ten opsigte van sy sosiale verhoudings.

- Die wanopvattings wat daar mag wees moet geïdentifiseer en saam deurgewerk word.

- Die berader moet dit nie as vanselfsprekend aanvaar dat hy sondermeer toegang gegun sal word tot die ervaringswêreld van die bedroefdes nie. Hy/sy sal met groot sensiwiteit daartoe moet werk om hierdie toegang te ontvang.

Die trauma maak 'n ingrypende impak op die wat agterbly se geloofslewe.

- Die geestelike of geloofsimpak van 'n selfmoord moet die kern wees waarop die berader fokus. 
- Alhoewel al die ander fasette noukeurig aandag moet kry, kan daar nie ware genesing plaasvind indien 'n persoon se geloofsvrae en -worsteling nie hanteer word nie.

\section{Konklusie}

Om iemand pastoraal te begelei na die selfmoord van ' $n$ geliefde is dit noodsaaklik om kennis te hê van die unieke impak wat selfmoord het op die wat agterbly. Sonder hierdie kennis mag die berader nie begryp waarom sy pastoraat dalk verwerp word, of die berading dalk heeltemal misluk nie.

\section{Geraadpleegde bronne}

ALEXANDER, V. 1991. Grief after suicide: giving a voice to the loss. Journal of geriatric psychiatry, 24:277-291.

BALCH, L.C. 1964. Toward an effective ministry relative to suicide. Saint Lukes's journal of theology, 7(2):22-31.

BARLOW, C. \& MORRISON, H. 2002. Those who are left behind: strategies to help survivors of suicide. Journal of psychosocial nursing, 40(1):29-38.

BARLOW, C.A. \& COLEMAN, J. 2003. Suicide and families: considerations for therapy. Guidance and counseling, 18(2):67-73.

BATTIN, M.P. 1982. Ethical issues in suicide. New York: Prentice-Hall.

BRENT, D., MORITZ, G., BRIDGE, J., PERPER J. \& CANOBBIO, R. 1996. The impact of adoloscent suicide on siblings and parents: a longitudinal followup. Suicide and life-threatening behavior, 26:253-259.

CHRISTIAN, R. 1997. What is the best way to serve those left behind? Leadership, 18:84-89, Fall.

DOUGLAS, J.D. 1967. The social meaning of suicide. New Jersey: Princeton University Press.

DU TOIT, P. 2004. Derde selfmoord tref skool: beradingsprogram te laat vir Centurion-seun wat druip. Beeld: 6, 22 Jul.

GIFFORD, E. \& STUART-SMITH, T. 1993. Pastoral care after suicide. St. Marks review, 152:34-39, Summer.

GOLDEN, T. 2005. Professional development - group methods in thanatology: why do men avoid support groups? Association for Death Education and Counseling, 31(3):1, 3.

HEIKES, K. 1997. Parental suicide: a systems perspective. Bulletin of the Menninger clinic, 61(3):354-368.

HOPMEYER, E. 1994. A comparative study of family bereavement groups. Death studies, 18(3):243-256.

KALISCHUK, R.G. \& HAYS, V.E. 2004. Grieving, mourning, and healing: following youth suicide: a focus on health and well-being in families. Omega, 48(1):45-67.

KNIEPER, A. 1999. The suicide survivor's grief and recovery. Suicide and lifethreatening behaviour, 29:253-346.

LEUVENNIK, J. 2002. Hoop vir gesinne in krisis: my familie. Sarie, (13):158160. 
LINN-GUST, M.S. 2006. Mode of death and the effects on sibling grief. Association for Death Education and Counseling, 32(1):1, 3.

MAUK, G.W. \& GIBSON, D.G. 1994. Suicide postvention with adolescents: school consultation practices and isssues. Education \& treatment of children, 17(4):468-484.

MURPHY, S.A. 1996. Parent bereavement stress and preventive intervention following the violent deaths of adolescent or young adolescent children. Death studies, 20(5):441-452.

NEIMEYER, R. BALDWIN, S. \& GILLIES, J. 2006. Continuing bonds and reconstructing meaning: mitigating complications in bereavement. Death studies, 30(8):715-738.

OLIVER, L. 1999. Effects of a child's death on the maritial relationship: a review. Omega, 39:197-227.

PIETILÄ, M. 2002. Support groups: a psychological or social device for suicide bereavement? British journal of guidance \& counselling, 30(4):401-414.

RASSOOL, M. 2002. Suicide: how does the church deal with it? The Southern cross: 13 March. http://www.scross.co.za/dealing_with_life/suicide.htm

SEEBER, L. 2002. The grief process after teenage suicide: an alternative. Vanderbijlpark: PU for CHE.

STRENGHT, J.M. 1999. Grieving the loss of a child. Journal of physchology and Christianity, 18(4):338-353.

THOMPSON, R.A. 1993. Posttraumatic stress and posttraumatic loss debriefing: brief strategic intervention for survivors of sudden loss. School counsellor, 41(1):16-22.

VAN DER WALT, M. 1988. Die lot van naasbestaandes: die naspel van 'n selfmoord. Woord en Daad, 28:4-5.

WERTHEIMER, A. 1991. A special scar: the experiences of people bereaved by suicide. London: Tavistock.

\section{Kernbegrippe:}

berading

emosionele impak

fisiese impak

godsdienstige impak

selfmoord

\section{Key concepts:}

counselling

emotional impact

physical impact

religious impact

suicide 
